\title{
Flexor-extensor relationship knee after reconstruction of the anterior cruciate ligament
}

\author{
Relação flexo-extensora de joelho após a \\ reconstrução do ligamento cruzado anterior
}

\author{
Cristiano Ingo Dagnoni ${ }^{[a]}$, Jaqueline Bilibiu ${ }^{[b]}$, Susan Stiehler ${ }^{[c]}$, Cássio Preis ${ }^{[\mathrm{d}]}$, Luiz Bertassoni Neto ${ }^{[\mathrm{e}]}$ \\ [a] Spec., Pontifícia Universidade Católica do Paraná (PUCR), Curitiba, PR - Brazil, e-mail: crisdagnoni@yahoo.com.br \\ [b] Spec., Pontifícia Universidade Católica do Paraná (PUCR), Curitiba, PR - Brazil, e-mail: jaquebilibiu@hotmail.com \\ [c] Spec., Pontifícia Universidade Católica do Paraná (PUCR), Curitiba, PR - Brazil, e-mail: sustiehler@yahoo.com.br \\ [d] MSc, professor, Pontifícia Universidade Católica do Paraná (PUCR), Curitiba, PR - Brazil, e-mail: cassio.preis@pucpr.br \\ [e] MSc, professor, Pontifícia Universidade Católica do Paraná (PUCR), Curitiba, PR - Brazil, e-mail: \\ luizbertassoni@yahoo.com.br
}

\begin{abstract}
Introduction: The incidence of knee injuries is very high in young adults. Anterior cruciate ligament (ACL) rupture is the most frequent of them. The isokinetic dynamometry evaluation determines the functional patterns of strength and muscle balance. Objective: To compare the isokinetic hamstring/quadriceps peak torque and work ratios of young adults after surgical reconstruction of the anterior cruciate ligament. Methods: We selected 33 medical records filed by the Isokinetic laboratory of the Physiotherapy Clinic of the Catholic University of Paraná (PUCPR), which belonged to patients who had undergone isokinetic assessment at the request of a physiotherapist or physician in Curitiba, Paraná. The tabulated data were: Hamstring/Quadriceps peak torque and work ratios of all injured and non-injured limbs at an angular velocity of $60^{\circ} \mathrm{s}$. Data were processed by the statistical software LHstat. Inferential statistics was used in order to apply the comparison test between means (unpaired t-test) with a confidence interval of $95 \%$. Results: The average flexion-extension ratio of the non-involved limb was lower than the involved limb both for peak torque (peak torque ratio of the non-involved limb: 56.1\%; peak torque ratio of the involved limb: 66.3\%; difference: 10.2\%) and work (work ratio of the non-involved limb: $60.1 \%$; work ratio of involved limb: 66.1\%; difference: 6\%). Conclusion: The average flexion/extension ratio found was adequate for both
\end{abstract}


limbs and variables, however, the subjects presented a greater number of muscle asymmetries in the involved limb than in the non-involved limb.

Keywords: Isokinetic. Knee. Anterior cruciate ligament (ACL).

\section{Resumo}

Introdução: A incidência de lesões de joelho em adultos jovens é muito alta, sendo a ruptura do ligamento cruzado anterior (LCA) a mais frequente. A avaliação por Dinamometria Isocinética determina o padrão funcional de força e equilíbrio muscular. Objetivos: Comparar a relação das variáveis isocinéticas torque e trabalho de flexores e extensores do joelho em adultos jovens após a reconstrução cirúrgica do ligamento cruzado anterior. Metodologia: Foram selecionados 33 prontuários arquivados pelo laboratório de Isocinética da Clínica de Fisioterapia da Pontifícia Universidade Católica do Paraná (PUCPR), de pacientes que realizaram a avaliação isocinética a pedido de fisioterapeutas e de médicos da cidade de Curitiba (PR). Os dados tabulados foram: relação flexora/extensora de pico de torque e trabalho em todos os membros lesionados e não-lesionados a uma velocidade angular de $60 \%$ s. Os dados foram tratados pelo software de estatística LHstat. A estatística inferencial foi empregada para aplicar o teste de comparação entre médias (Teste t não pareado) com um intervalo de confiança de 95\%. Resultados: A média da relação flexo-extensora é menor no membro não envolvido tanto no pico de torque (relação pico de torque do membro não envolvido 56,1\% e relação do pico de torque do membro envolvido 66,3\%, apresentando diferença de 10,2\%) quanto no trabalho (relação do trabalho no membro não envolvido 60,1\% e relação do trabalho do membro envolvido 66,1\% apresentando diferença de 6\%). Conclusão: A média encontrada da relação flexo-extensora foi adequada para ambos os membros e variáveis, no entanto os indivíduos apresentaram assimetrias musculares em maior número no membro envolvido do que no membro não envolvido.

Palavras-chave: Isocinética. Joelho. Ligamento cruzado anterior (LCA).

\section{Introduction}

The incidence of knee injuries is very high in young adults and reaches approximately $70 \%$ in sports practice. Anterior cruciate ligament (ACL) disruption is the most frequent of these injuries and males are usually more affected by it. However, the incidence in females is increasing every year $(1,2,3)$.

The ACL is responsible for about $85 \%$ of the anterior stabilization of the knee joint. The signs and symptoms that indicate its rupture include: joint stroke, cracking, missteps, pain and difficulty in performing some daily life activities. Nevertheless, some individuals do not report symptoms and are classified as adapted to the injury. Surgery candidates usually present motor impairments and have the intention of returning to sport $(4,5)$.

Among the surgical reconstruction procedures available, the most common grafts are derived from the patellar tendon, the tendon of the semitendinosus muscle, cadavers (allograft), or are synthetic grafts. Morbidity of the site the graft is acquired from, muscle weakness associated with initial injury and the surgical procedure itself are factors that may interfere with postoperative recovery $(6,7)$. In injured knees, the hamstrings act as ACL synergists and help reduce the incidence of new ligament injuries (8). Even if the knee presents stability and good range of motion, the ultimate goal of surgical reconstruction cannot be achieved without the recovery of muscle strength $(8,9)$.

The interest in assessing muscle performance of the knee extensors and flexors is due to the fact that they are reference values for the isokinetic and functional recovery progression and the return to sports $(10,11)$. Isokinetic dynamometry is a reliable method of determining the functional pattern of muscle strength and balance. In this context, isokinetic variables such as peak torque, work, and power are important. The application of these variables in the balance relationship between flexors and extensors (FLEX/EXT) of the knee has been identified as an 
important tool to evaluate the functional ability of joints and to calculate indices of injury risk $(12,13)$.

Thus, the aim of this study was to compare the isokinetic hamstring/quadriceps peak torque and work ratios.

\section{Materials and methods}

This is an applied study. We used a quantitative descriptive approach and the research design was ex-post facto and documental (14).

Data collection was performed in August 2010. We collected data from October 2007 to June 2010, through the selection of 33 medical records archived by the Isokinetic laboratory of the Physiotherapy Clinic of the Catholic University of Paraná (PUCPR) which met inclusion and exclusion criteria. Inclusion criteria were: male gender; age between 20 and 30 years; postoperative (PO) ACL reconstruction with semitendinosus graft and Isokinetic assessment performed 4-8 months after surgery. Exclusion criteria were: a bilateral knee injury; musculoskeletal and joint disorders of the knees; systemic and neurological diseases.

All of the selected records belonged to patients who had undergone isokinetic assessment at the request of a physiotherapist or physician in the city of Curitiba. There was, therefore, no prior contact with any recovery stage. Individuals undergoing the isokinetic testing were previously assessed through the use of a physical therapy record, on which personal data, height (estimated by use of stadiometer), body weight (assessed by scale), clinical diagnosis, and other data were recorded. After this first contact was made, patients performed a 5-minute warm-up on a cycle ergometer with $5 \mathrm{Kpm}$ load.

This was followed by the isokinetic assessment, which was performed by using the Cybex isokinetic dynamometer (model Norm 700). All assessments were performed by only one experienced reviewer. The non-involved member was tested first. The patient was sitting down when the measurement was taken and all parameters recommended by the manufacturer were followed: slightly reclined trunk; properly stabilized trunk, thigh and legs; axis of rotation of the lever arm was properly aligned to the lateral femoral condyle. Range of motion in the knee was $100^{\circ}$ of flexion to $0^{\circ}$ of extension. The procedure was fully explained to the patient, who performed a specific warming-up, two submaximal contractions and one maximum contraction for familiarization and recruitment of motor units. An angular velocity of $60^{\circ} / \mathrm{s}$ was measured in concentric mode and the patient performed three maximum repetitions.

The tabulated data were: Hamstring/Quadriceps peak torque and work ratios in all injured and uninjured limbs at an angular velocity of $60^{\circ} \%$ s. The postoperative time period and the side involved were also assessed. The Body Mass Index (BMI) of the entire sample was calculated as body weight divided by height squared $\left(\mathrm{kg} / \mathrm{m}^{2}\right)$. Data were then processed by the statistical software LHstat and presented though descriptive statistics, graphs and tables. The inferential statistics was used in order to apply the comparison test between means (unpaired t-test) with a confidence interval of $95 \%$.

Peak torque ratios between $49.9 \%$ and $69.9 \%$ were considered to be normal or appropriate (both for peak torque and work). Values above $69.9 \%$ and below $49.9 \%$ were considered to be abnormal or inadequate.

\section{Results}

The average body weight was $78.6 \pm 7.58 \mathrm{~kg}$ (minimum of $60 \mathrm{~kg}$ and maximum of $90 \mathrm{~kg}$ ). The average height was $1.78 \pm 0.06 \mathrm{~m}$ (minimum of $1.63 \mathrm{~m}$ and maximum of $1.91 \mathrm{~m}$ ). The BMI average was $24.76 \pm$ $2.20 \mathrm{~kg} / \mathrm{m}^{2}$ (minimum of $20.76 \mathrm{~kg} / \mathrm{m}^{2}$ and maximum of $29.41 \mathrm{~kg} / \mathrm{m}^{2}$ ). We found that 22 subjects had a healthy BMI (normal range between 18.5 and 24.9 $\mathrm{kg} / \mathrm{m}^{2}$ ) and 11 subjects were above the recommended weight ( 25 to $29.9 \mathrm{~kg} / \mathrm{m}^{2}$ ).

Regarding the anatomic distribution of the injury, among the 33 cases selected, 15 cases (45.45\%) had injured the nondominant limb and 18 (54.55\%) had injured the dominant limb. Most of the subjects (60.61\%) were evaluated after 4-5 months (60.61\%) and 39.39\% were assessed after 6-8.

Table 1 shows the descriptive statistical findings of the following variables: hamstring/quadriceps peak torque ratio in the non-involved limb (PTRNI); hamstring/quadriceps peak torque ratio in the involved limb (PTRI); quadriceps-to-hamstring work ratio in the non-involved limb (WRNI) and quadriceps-tohamstring work ratio in the involved limb (WRI).

The PTRNI obtained approximately $75.8 \%$ of the sample with values between $49.9 \%$ to $69.9 \%$. The PTRI obtained approximately $60.6 \%$ of the sample 
with values between $49.9 \%$ to $69.9 \%$. The average PTRNI was $56.1 \%$, and the average PTRI was $66.3 \%$. Thus, the difference between members was $10.2 \%$, considered statistically significant $(\mathrm{p}<0.05)$. The average comparison test was performed with paired data and a normal distribution of sample means at a significance level of 5\%. Student's t value was $<1 \%$ error. Thus, PTRI is higher than PTRNI.

The WRNI obtained approximately $81.8 \%$, with values between $49.9 \%$ and $69.9 \%$. However, the WRI obtained about $69.7 \%$ of the sample, with values between $49.9 \%$ and $69.9 \%$. The average WRNI was $60.1 \%$, and the average WRI was $66.1 \%$. Thus, the difference between limbs was $6 \%$, considered statistically significant $(\mathrm{p}<0.05)$. The average comparison test was also performed with paired data and a normal distribution of sample means at a significance level of $5 \%$. Student's t value was $<2 \%$ error. Thus, WRI is higher than WRNI

Tests of normality and homoscedasticity were performed for the analysis of the variables (PTRNI, PTRI, WRI and WRNI). The Shapiro-Wilk normality test accepts the hypothesis of normal distribution. A significance level of $5 \%$ or 0.05 was used. If the p-value is below 0.05 , the hypothesis of normality for the variable analyzed is rejected. The PTRNI and WRNI variables had $p$-values $>0.05$; which denotes a normal distribution. The PTRI and WRI variables, on the other hand, had p-values $<0.05$; which denotes an abnormal distribution. This change is due to the high value of standard deviation associated with these variables, which are related to the injured knee.

The homoscedasticity test supports the hypothesis of uniform variance of distribution is also based on the p-value and has a significance level of 0.05. All of the analyzed variables analyzed showed values $>0.05$; which indicates the homogeneity of the sample. With a sample of 33 individuals, it is not necessary that its variables follow the normal distribution, because, regardless of the distribution of these variables, their average will be close enough to the normal distribution in order to allow for the use of the t-test (15).

Table 2 shows the distribution of normal and abnormal cases among the variables, both in absolute value and in percentage. We found a greater hamstrings weakness values in the non-involved lower limb for the peak torque variable. However, for all other variables, quadriceps weakness values were higher, even though the sample was constituted by subjects who had undergone ACL reconstruction using a graft of the semitendinosus muscle.

Table 3 shows the distribution of cases of quadriceps-to-hamstring peak torque and work ratios, according to postoperative months and in absolute number and percentage.

Regarding the peak torque, we observed that 14 subjects had muscle balance and 19 subjects still presented alterations in this aspect, both bilaterally and unilaterally. With regards to work, 20 subjects showed balance, while 13 subjects showed alterations from normality.

According to the data from Table 3, there are more individuals with muscle dysfunction or deficit in the involved limb than in the non-involved limb, independent of the month considered. However, the study also found changes in muscle strength in both limbs.

Data crossing of BMI data with standard values for the agonist-antagonist ratio (49.9\% to $69.9 \%$ ) resulted in the formation of two groups: normal BMI and overweight BMI. 15.2\% of the sample had normal BMI and balance of the agonist-antagonist ratio, $27.3 \%$ of the sample showed weakness of the extensor muscles, $21.2 \%$ showed weakness of the flexor muscles, and only 3\% showed weakness of both agonists and antagonists.

Table 1 - Comparison of the hamstring/quadriceps peak torque ratio: descriptive statistical findings

\begin{tabular}{|c|c|c|c|c|}
\hline \multirow{2}{*}{ Variable } & \multicolumn{2}{|c|}{ Peak torque } & \multicolumn{2}{|c|}{ Work } \\
\hline & Non-involved limb & Involved limb & Non-involved limb & Involved limb \\
\hline Minimum & $41.8 \%$ & $36.5 \%$ & $46.3 \%$ & $36.9 \%$ \\
\hline Maximum & $70.4 \%$ & $129.5 \%$ & $75.3 \%$ & $127.9 \%$ \\
\hline Average & $56.1 \pm 7.4 \%$ & $66.3 \pm 18 \%$ & $60.1 \pm 7.4 \%$ & $66.1 \pm 17.1 \%$ \\
\hline
\end{tabular}

Source: Research data. 
Table 2 - Distribution of cases among the variables (absolute value and percentage)

\begin{tabular}{|c|c|c|c|c|c|c|}
\hline \multirow{2}{*}{ Variable } & \multirow{2}{*}{\multicolumn{2}{|c|}{$\begin{array}{c}\text { Normal }^{*} \\
\text { (Quantity) } \\
\end{array}$}} & \multicolumn{2}{|c|}{ Abnormal $^{* *}$} & \multirow[b]{2}{*}{ Total } & \multirow[b]{2}{*}{$\%$} \\
\hline & & & Higher & Lower & & \\
\hline PTRNI & 25 & $75.8 \%$ & 1 & 7 & 8 & $24.2 \%$ \\
\hline PTRI & 20 & $60.6 \%$ & 9 & 4 & 13 & $39.4 \%$ \\
\hline WRNI & 27 & $81.8 \%$ & 4 & 2 & 6 & $18.2 \%$ \\
\hline WRI & 23 & $69.7 \%$ & 8 & 2 & 10 & $30.3 \%$ \\
\hline
\end{tabular}

Note: PTRNI = hamstring/quadriceps peak torque ratio of the non-involved limb; PTRI = hamstring/quadriceps peak torque ratio of the involved limb; WRNI = quadriceps-to-hamstring work ratio of the non-involved limb; WRI = quadriceps-to-hamstring work ratio of the involved limb; ${ }^{*}$ Normal = PTRNI and PTRI are between 49.9 and $69.9 \% ;{ }^{* *}$ Abnormal $=$ Higher than $69.9 \%$ and Lower than $49.9 \%$. Source: Research data.

Table 3 - Distribution of cases among the variables (absolute value and percentage)

\begin{tabular}{|c|c|c|c|c|c|c|c|c|c|c|c|}
\hline \multicolumn{6}{|c|}{ Peak torque } & \multicolumn{6}{|c|}{ Work } \\
\hline \multirow{2}{*}{$\begin{array}{c}\text { Time } \\
\text { (months) }\end{array}$} & \multirow{2}{*}{$\begin{array}{c}\text { Normal } \\
* \\
\text { n (\%) }\end{array}$} & \multicolumn{4}{|c|}{$\underset{\star \star \star}{\text { Abnormal }}$} & \multirow{2}{*}{$\begin{array}{c}\text { Time } \\
\text { (months) }\end{array}$} & \multirow{2}{*}{$\begin{array}{c}\text { Normal } \\
* \\
\text { n (\%) }\end{array}$} & \multicolumn{4}{|c|}{$\underset{* \star}{\text { Abnormal }}$} \\
\hline & & 1 & $\mathrm{NI}$ & $\underset{* * *}{N o n e}$ & $\%$ & & & I & $\mathrm{NI}$ & $\underset{* * *}{\text { None }}$ & $\%$ \\
\hline 4 & 5 (15.2\%) & 5 & 1 & 2 & 24.2 & 4 & $8(24.2 \%)$ & 2 & 2 & 1 & 15.2 \\
\hline 5 & 3 (09.1\%) & 2 & 1 & 1 & 12.1 & 5 & 5 (15.2\%) & 2 & 0 & 0 & 06.0 \\
\hline 6 à 8 & 6 (18.2\%) & 4 & 2 & 1 & 21.2 & 6 à 8 & 7 (21.2\%) & 4 & 1 & 1 & 18.2 \\
\hline Total & 14 (42.5\%) & 11 & 4 & 4 & 57.5 & Total & $20(60.6 \%)$ & 8 & 3 & 2 & 39.4 \\
\hline
\end{tabular}

Note: I = involved limb; $\mathrm{NI}=$ non-involved limb; *Normal = NI and I are between 49.9 and 69.9\%; **Abnormal = NI and I are lower than $49.9 \%$ and/or higher than $69.9 \% ;{ }^{* * *}$ None $=$ none of the lower limbs has any values between 49.9 and $69.9 \%$.

Source: Research data.

$21.2 \%$ of the sample had overweight BMI and shoed balance of agonist-antagonist ratio, 9.1\% showed weakness of extensor muscles and $3 \%$ showed weakness of the hamstrings.

\section{Discussion}

The isokinetic assessment has been used in recent decades as a method to determine the functional pattern of muscular strength and balance through the analysis of the following variables: peak torque and agonist-antagonist balance ratio. The angular velocity of $60^{\circ} \% \mathrm{~s}$ is widely used to evaluate the maximum joint moment given in torque, basically for two reasons: the first is that, the smaller the angular velocity the larger the torque; the second is because at this speed there will hardly be fatigue, obviously respecting the maximum number of 3 repetitions. In the present study, we used the flexor/extensor (FLX/EXT) ratio as an assessment parameter, because it is an indicator of normality with regard to the balance between the function of the extensors and flexors of the knee. There is a $50-70 \%$ oscillation in the flexor/extensor ratio of the healthy knee joint $(12,16,17,18,19)$.

Normally, muscle imbalances in the knee are assessed using the conventional ratio (concentric hamstrings/concentric quadriceps). Values between 0.5 and 0.7 are considered normal. FLX/EXT ratio around $60 \%$, at an angular velocity of $60^{\circ} / \mathrm{s}$, had 
good acceptability; there is, however, no consensus on the desired normative value. Nevertheless, the use of the conventional ratio alone has limitations since it represents a situation that is absent during the execution of functional movements. Therefore, the functional ratio (eccentric flexor peak torque/ extensor concentric peak torque ) is currently used for this evaluation. Changes in this ratio predispose to injury in the knee joint and strains in the hamstring muscles $(17,19,20,21,22,23)$. In the present study we could confirm average values of 50 to $70 \%$ for the agonist-antagonist ratio within 4 to 8 months of postoperative reavaluation in the absolute majority of the sample.

Quadriceps muscle atrophy, instability and pain are clinical complaints that may be explained by deficits in muscle performance after the recovery process $(20,24,25)$.

The loss of muscle strength is associated with proprioceptive loss, thus, one should be cautious when using the non-injured side as a normal parameter for the injured side, because the injured side can influence the contralateral side $(4,17)$.

Studies in subjects with ACL disruption show that return to function at pre-injury level is dependent on the knee extensor strength and that return to a functional level is positively correlated with muscle strength assessments. The FLX/EXT ratio in healthy individuals reaches between $50 \%$ and $60 \%$ and the increase in FLX/EXT is probably due to a extensor muscle strength deficit (10).

Loss of muscle strength in the postoperative ACL reconstruction population has been frequently documented because it is a limiting factor for the return to physical activities. Isokinetic assessment allows more precise measurements and has a major impact on clinical decision making. Among the tests and equipments developed for evaluation of muscle performance of the knee extensors and flexors, computerized isokinetic dynamometers are considered gold standard. Values obtained in the isokinetic test are, in theory, more realistic in relation to maximum muscle functional capacity. Some studies have indicated higher knee extensor peak torque values for the non-involved limb than for the involved limb. They allege that the recovery of the extensor mechanism is slow and difficult. After ACL rupture, it is possible to identify a greater weakness of quadriceps than hamstrings (26). In another study, it was shown that, even after five years of ACL reconstruction (26), during which time the recovery of muscle function is expected, physical evaluation revealed a deficit in muscle strength $(11,26,27,28,29,30,31)$.

In a survey, eleven amateur-level athletes (29) were evaluated months after ACL reconstruction using patellar tendon autogtraft. Its results show that the FLX/EXT ratio is lower on the involved side. On the other hand, the assessment of twenty-eight athletes who had ACL laxity or not (31), could not detect significant differences in FLX/EXT ratios between the two groups. This evidences that ACL laxity does not affect knee joint muscle balance. Another study evaluated 6 patients in the preoperative and postoperative period on two occasions (31): after 4 months and one year. An imbalance in the FLX/EXT relationship after ACL reconstruction was found, especially in the period of 4 months after surgery $(21,29,31,32)$. Our study found a higher FLX/EXT ratio on the injured limb, when compared to the non-injured side. This suggests a deficit of the extensor muscles. Our results show a higher FLX/EXT ratio on the reconstructed knee both in the peak torque (10\% deficit between limbs) and in work (6.3\% deficit between limbs).

A muscle-ligament reflex prevents excessive Anterior Tibial Translation (ATT). It promotes the inhibition of the quadriceps and the activation of the hamstring, which act as a dynamic agonist of the ACL in injured individuals (27). However, there is a significant difference in the agonist/antagonist relation, due to the quadriceps deficit and a little loss of strength of hamstrings, promoting an imbalance in the relationship. During the postoperative recovery the readjustment of the FLX/EXT relationship is sought. However, an excessive development of quadriceps strength contributes to a decreased antagonist coactivation of the hamstrings and favors ligament rupture, due to the decrease in the stabilizing forces of this joint $(8,18,22,27,32,33)$.

Muscle imbalances detected by the FLX/EXT ratio are associated with a higher incidence of injury in athletes. The current literature shows evidence that the muscle coactivation that takes place in the knee would serve to protect and stabilize the joint during powerful muscle contractions. Moreover, it would be responsible for distributing pressure across the joint and minimizing fatigue and joint damage $(24,34)$.

Among soccer and futsal players (35), the FLX/ EXT ratio at $60^{\circ} / \mathrm{s}$ had an average of $54.7 \%$. The authors suggested that the ideal ratio for football players was $65 \%$. Other studies (36), found a FLX/EXT of 
$60.7 \%$ (at the same speed) in men and an average of 48 and 51\% in young volleyball players (37).

Thus, in the present study, the involved limb presented higher averages of FLX/EXT peak torque and work ratios. Even though within the normal range ( $49.9 \%$ to $69.9 \%$ ), they were closer to the superior boundary value, which suggests a tendency for extensor muscle strength deficiency. It can be observed, taking the value of normality as parameter, that there was a decrease of approximately $15 \%$ of the total sample for the peak torque ratio and $12 \%$ of the total sample for the work ratio, when the non-injured limb was compared with the injured. The lowest absolute percentage of the sample found in the involved limbs may suggest the process of functional recovery, which is still in continuity. This correlation further demonstrates the difficulty in achieving muscular balance during post-surgical recovery process, given the fact that not even the healthy limb reached $100 \%$ of normality.

In sedentary people, muscle imbalances values lower than $10 \%$ are considered normal and acceptable. However, in athletes, imbalance values superior to $5 \%$ may, sometimes, already be important, because their muscles must be well conditioned for maximum performance during sports activity (38). The imbalance between the strength of the quadriceps and hamstring muscles suggests not to exceed the potential strength of the quadriceps more than $10 \%$ in relation to the hamstring muscles, in order to protect the joints and muscles. It is stated that a reduction of 50-60\% of the strength of the hamstrings to the quadriceps predisposes to injury. A careless strength training of the hamstring muscles may reduce coactivation of antagonists in response to the superiority of quadriceps strength (38). We found in this study, a bilateral difference of $10.2 \%$ for the FLX/EXT peak torque ratio and $6 \%$ for the work ratio, which brings a concern about the imbalance found, given the fact that, in a sample of physically active people, such indices may be interpreted as a risk of injury.

\section{Conclusion}

Muscle balance was presented by some subjects, but not by the whole sample. We found lower normal FLX/EXT peak torque ratios unilaterally than bilaterally. With regard to the work, the study revealed that most of the sample presented muscle balance and a smaller part presented asymmetries. Regarding the measuring variables (peak torque and work), individuals presented a great number of muscle deficits in the involved limb than in the non-involved limb.

Therefore, we suggest the need to promote greater attention to the functional recovery of muscle strength of the limb involved by the lesion, yet without forgetting the importance of maintaining muscle strength and balance of the contralateral limb, both in bilateral balance and FLX/EXT ratio.

\section{References}

1. Kisner C, Colby LA. Exercícios terapêuticos: fundamentos e técnicas. 4. ed. São Paulo: Manole; 2005.

2. Tria AJ. Lesões ligamentares do joelho: anatomia, diagnóstico, tratamento e resultados. Rio de Janeiro: Revinter; 2002.

3. Cohen M. Tratado de Ortopedia. São Paulo: Roca; 2007.

4. Fatarelli IFC, Almeida GL, Nascimento BG. Lesão e reconstrução do LCA: uma revisão biomecânica e do controle motor. Rev Bras Fisioter. 2004;8(3):197-206.

5. Silva R, Matos MA, Silva DJA, Abreu MS. Associação entre tempo de rupturas do ligamento cruzado anterior e frequência de outras lesões articulares do joelho. Rev Bras Ortop. 2006;41(7):268-71.

6. Eriksson K, Hamberg P, Jansson E, Larsson H, Shalabi A, Wredmark T. Semitendinosus muscle in anterior cruciate ligament surgery: morphology and function. Arthroscopy. 2001;17(8):808-17.

7. Vasconcelos RA, Bevilaqua-Grossi D, Shimano AC, Paccola CJ, Salvini TF, Prado CL, et al. Análise da correlação entre pico de torque, desempenho funcional e frouxidão ligamentar em indivíduos normais e com reconstrução do ligamento cruzado anterior. Rev Bras Ortop. 2009;44(2):134-42.

8. Rosene JM, Fogarty TD, Mahaffey BL. Isokinetic hamstrings: quadriceps ratios in intercollegiate athletes. J Athl Train. 2001;36(4):378-83.

9. Kobayashi A, Higuchi H, Terauchi M, Kobayashi F, Kimura M, Takagishi K. Muscle performance after anterior cruciate ligament reconstruction. Int Orthop. 2004;28(1):48-51. 
10. Hiemstra LA, Webber S, MacDonald PB, Kriellaars DJ. Hamstring and quadriceps strength balance in normal and hamstring anterior cruciate ligament-reconstructed subjects. Clin J Sport Med. 2004;14(5):274-80.

11. Vasconcelos RA, Bevilaqua-Grossi D, Shimano AC, Paccola CJ, Salvini TF, Prado CL, et al. Confiabilidade e validade de um dinamômetro isométrico modificado na avaliação do desempenho muscular em indivíduos com reconstrução do ligamento cruzado anterior. Rev Bras Ortop. 2009;44(3):214-24.

12. Machado SM, Souza RA, Simão AP, Jerônimo DP, Silva NS, Osorio RAL, et al. Estudo comparativo de variáveis isocinéticas do joelho em atletas de taekwondo e kickboxing. Fit Perf J. 2009;8(6):407-11.

13. Goulart LF, Dias RMR, Altimari LR. Variação do equilíbrio muscular durante uma temporada em jogadores de futebol categoria sub-20. Rev Bras Med Esporte. 2008;14(1):17-21.

14. Gil AC. Como elaborar projetos de pesquisa.4. ed. São Paulo: Atlas; 2002.

15. Loesch C. Probabilidade e estatística. Rio de Janeiro: LTC; 2012.

16. Bowerman SJ, Smith DR, Carlson M, King GA. A comparison of factors influencing ACL injury in male and female athletes and non-athletes. Phys Ther Sport. 2006;7(3):144-52.

17. Kong PW, Burns SF. Bilateral difference in hamstrings to quadriceps ratio in healthy males and females. Phys Ther Sport. 2010;11(1):12-7.

18. Holcomb WR, Rubley MD, Lee HJ, Guadagnoli MA. Effect of hamstring-emphasized resistance training on hamstring: quadriceps strength ratios. J Strength Cond Res. 2007;21(1):41-7.

19. Terreri ASAP, Greve JMD, Amatuzzi MM. Avaliação isocinética no joelho do atleta. Revista Brasileira de Medicina do Esporte. 2001;7(5):170-4.

20. Rezende GF, Pereira LB, Bittencourt L. Dados normativos de força concêntrica, excêntrica, relação agonista/ antagonista e relação funcional do joelho em atletas de futebol. Anais do 1. Congresso Brasileiro de Fisioterapia Esportiva, 2004, Guarujá. São Paulo: Sociedade Nacional de Fisioterapia Esportiva; 2004.
21. Fonseca ST, Ocarino JM, Silva PLP, Bricio RS, Costa CA, Wanner LL. Caracterização da performance muscular em atletas profissionais de futebol. Rev Bras Med Esporte. 2007;13(3):143-7.

22. Coombs R, Garbutt G. Developments in the use of the hamstring: quadriceps ratio for the assessment of muscle balance. J Sports Sci Med. 2002;1(3):56-62.

23. Weber FS, Silva BGC, Radaelli R, Paiva C, Pinto RS. Avaliação isocinética em jogadores de futebol profissional e comparação do desempenho entre as diferentes posições ocupadas no campo. Rev Bras Med Esporte. 2010;16(4):264-8.

24. Pássaro AC, Marques AP, Sacco ICN, Amadio AC, Bacarin TA. Mecanismos de ativação agonista e antagonista no joelho de indivíduos com reconstrução de ligamento cruzado anterior: estudo cinético e eletromiográfico. Acta Ortop Bras. 2008;16(2):117-21.

25. Dvir Z. Isocinética: avaliações musculares, interpretações e aplicações clínicas. São Paulo: Manole; 2002.

26. Lautamies R, Harilainen A, Kettunen J, Sandelin J, Kujala UM. Isokinetic quadriceps and hamstring muscle strength and knee function 5 years after anterior cruciate ligament reconstruction: comparison between bone-patellar tendon-bone and hamstring tendon autografts. Knee Surg Sports Traumatol Arthrosc. 2008;16(11):1009-16.

27. Vasconcelos RA, Arakaki JC, Simão AP, Oliveira AS, Paccola CJ, Bevilaqua-Grossi D. Análise da translação anterior da tíbia, pico de torque e atividade eletromiográfica do quadríceps e isquiotibiais em indivíduos com lesão do ligamento cruzado anterior em cadeia cinética aberta. Acta Ortop Bras. 2007;15(1):14-8.

28. Aquino CF, Vaz DV, Brício RS, Silva PLP, Ocarino JM, Fonseca ST. A utilização da dinamometria isocinética nas ciências do esporte e reabilitação. R Bras Ci e Mov. 2007;15(1):93-100.

29. Jamshidi AA, Olyaeia GR, Heydarian K, Talebian S. Isokinetic and functional parameters in patients following reconstruction of the anterior cruciate ligament. IES. 2005;13(4):267-72.

30. Pincivero DM, Heller BM, Hou SI. The effects of ACL injury on quadriceps and hamstring torque, work and power. J Sports Sci. 2002;20(9):689-96. 
31. Portes EM, Portes LA, Botelho VG, Pinto SS. Isokinetic torque peak and hamstrings/quadriceps ratios in endurance athletes with anterior cruciate ligament laxity. Clinics. 2007;62(2):127-32.

32. Traete RF, Pinto KNZ, Mattiello-Rosa SM. Relationship between chondral lesion and peak torque following anterior cruciate ligament reconstruction: case study. Rev Bras Fisioter. 2007;11(3):239-43.

33. Ageberg E, Roos HP, Silbernagel KG, Thomeé R, Roos EM. Knee extension and flexion muscle power after anterior cruciate ligament reconstruction with patellar tendon graft or hamstring tendons graft: a crosssectional comparison 3 years post surgery. Knee Surg Sports Traumatol Arthrosc. 2009;17(2):162-9.

34. Iga J, George K, Lees A, Reilly T. Cross-sectional investigation of indices of isokinetic leg strength in youth soccer players and untrained individuals. Scand J Med Sci Sports. 2009;19(5):714-9.

35. Alexandre PF, Lacerda RC, Deus LA, Melo FT, Alves MGS. Análise comparativa do desempenho muscular isocinético entre jogadores de futebol e futsal. Educ Fís Rev. 2009;3(2):1-12.
36. Hewett TE, Myer GD, Zazulak BT. Hamstrings to quadriceps peak torque ratios diverge between sexes with increasing isokinetic angular velocity. J Sci Med Sport. 2008;11(5):452-9.

37. Bittencourt NFN, Amaral GM, Anjos MTS, D’Alessandro RD, Silva AA, Fonseca ST. Isokinetic muscle evaluation of the knee joint in athletes of the under-19 and under-21 male Brazilian national volleyball team. Rev Bras Med Esporte. 2005;11(6):302-6.

38. Assis MMV, Gomes MI, Carvalho EMS. Avaliação isocinética de quadríceps e ísquios-tibiais nos atletas de jiu-jitsu. Rev Bras Promoç Saúde. 2005;18(2):85-9.

Received: 06/17/2013

Recebido: 17/06/2013

Approved: 02/05/2014

Aprovado: 05/02/2014 